\title{
THE EFFECT OF CALCIUM SILICATE ON THE PHOSPHORUS SORPTION CHARACTERISTICS OF ANDISOLS LEMBANG WEST JAVA
}

\author{
Arief Hartono \\ Department of Soil Science and Land Resource, \\ Faculty of Agriculture, Bogor Agricultural University (IPB) \\ Jalan Meranti, Kampus IPB Darmaga 16680
}

\begin{abstract}
The effect of calcium silicate $\mathrm{CaSiO}_{3}$ the phosphorus $(P)$ sorption characteristics were studied in Andisols Lembang. The amount of 0, 2.5 and $5 \% \mathrm{CaSiO}_{3}$ (calcium silicate) or $0,7.5$ and $15 \mathrm{~g}$ calcium silicate per pot was added to the $300 \mathrm{~g}$ (oven-dry weight) soil and incubated for one month. A completely randomized design in double replication was set up. After one month incubation, $P$ sorption and $P$ sorption kinetic experiments were conducted. The results of $P$ sorption experiment showed that $P$ sorption data were satisfactorily described by the Langmuir equation, which was used to determine $P$ sorption maxima, bonding energies and $P$ sorbed at $0.2 \mathrm{mg} P L^{-1}$ (standard $P$ requirement). The application of calcium silicate did not affect significantly $P$ sorption maxima but decreased significantly the $P$ bonding energies. Calcium silicate also decreased significantly the standard $P$ requirements. As for $P$ sorption kinetic experiment, the results showed that application of $5 \%$ calcium silicate decreased significantly the rate constant of $P$ sorption and $P$ sorbed maximum at given amount of added $P$. The results suggested that the application of calcium silicate to the Andisols made added $P$ was more crvailable for plant.
\end{abstract}

Key words: Andisols Lembang, calcium silicate, kinetic, P sorption

\section{INTRODUCTION}

Andisols in Lembang west Java is extensively used by farmers for horticulture. The knowledges concerning the behaviour of nutrients in this soil are very important to uplift the production of the crops. One of the most important nutrient after nitrogen is phosphorus $(P)$. It is well known that Andisols exhibit the high $P$ sorption capacity due to the type of clay minerals.

Andisols Lembang was dominated by amorphous silicate clay mineral allophane and amorphous aluminum ( $\mathrm{Al}$ ) and iron ( $\mathrm{Fe}$ ) oxides extracted by ammonium oxalate (Tan and Van Schuylenborgh, 1961; Tan, 1965). These kinds of clay mineral has large capacities to sorb P (Wada, 1959; Birell, 1961; Fassbender, 1968; Kingo and Pratt, 1971; Beck et al., 1999; Van Ranst et al., 2004). As a result, most of added $P$ in Andisols Lembang will be sorbed by these clay minerals. $P$ sorbed in this soil was reported difficult to be desorbed due to high bonding energy of $P$ sorption (Beck et al., 1999).

The use of $\mathrm{CaSiO}_{3}$ (calcium silicate) in Andisols Lembang was reported to enhance the transformation of chemisorbed $P$ pool to biologically available $P$ (resin- $P$ inorganic) pool (Hartono, 2007). It means that calcium silicate is promising ameliorant for mining unavailable $\mathrm{P}$ which was accumulated in this soil. Further research concerning the effect of calcium silicate application on the $P$ sorption characteristics is needed. It is related to $P$ sorption maximum, bonding energy, $P$ sorbed at $0.2 \mathrm{mg} \mathrm{L}^{-1}$ (standard $P$ requirement) and the kinetic of $P$ sorption. Those parameters were positively correlated with plant uptake for P (Fox and Kamprath, 1970).

The objectives of this study were to evaluate the effect of calcium silicate on the $P$ sorption characteristics concerning $\mathrm{P}$ sorption maximum, bonding energy, standard $P$ requirements and the kinetic of $P$ sorption of Andisols Lembang.

\section{MATERIALS AND METHODS}

Soil sample. Soil samples of surface horizon of cultivated Andisols were collected. The coordinate of sampling site was S $6^{\circ} 48^{\prime} 5^{\prime \prime}$ and E $107^{\circ} 39^{\prime} 0^{\prime \prime}$. Soil samples were air-dried and crushed to pass through a $2-\mathrm{mm}$ mesh sieve.

Methods of initial soil analyses. $\mathrm{pH}$ was measured in a $1: 1.5(\mathrm{w} / \mathrm{v})$ water solution using a $\mathrm{pH}$ meter. Clay content was determined by the pipet method where Jeffries method described by Jeffries (1947) was used to disperse soil particles. Clay minerals were identified by $\mathrm{X}$-ray diffraction analysis (Rigaku RAD-2RS Diffractometer). The content of organic carbon (C) in soil was measured with a NC analyzer (Sumigraph NC analyzer NC-800-13 N, Sumika Chem. Anal. Service). Available P content was obtained by the Bray I method (Bray and Kurtz, 1945) while total $\mathbf{P}$ was determined by digesting the soil sample using concentrated percloric acid and nitric acid as described by Kuo (1996). Their absorbance at $693 \mathrm{~nm}$ was determined using a UV-VIS spectrophotometer (UV-1200, Shimadzu Corporation, Japan). Cation exchange capacity (CEC) was obtained by extraction with $1 \mathrm{~mol} \mathrm{~L}^{-1} \mathrm{NH}_{4} \mathrm{OAC}$ $\mathrm{pH} 7.0$ and the contents of exchangeable bases calcium $\left(\mathrm{Ca}^{2+}\right)$ and magnesium $\left(\mathrm{Mg}^{2+}\right)$ were determined by atomic absorption spectrophotometry (AA-640-12, Shimadzu Corporation, Japan) while those of exchangeable potassium $\left(\mathrm{K}^{+}\right)$and sodium $\left(\mathrm{Na}^{+}\right)$were determined by flame emission spectrophotometry (AA-640-12, Shimadzu Corporation, 
Japan). Base saturation was defined as the ratio of total exchangeable bases to CEC, expressed as a percentage. Exchangeable Aluminum (Al) was extracted with $1 \mathrm{~mol} \mathrm{~L}^{-1}$ $\mathrm{KCl}$.

The contents of oxalate-extractable $\mathrm{Fe}$ and $\mathrm{Al}\left(\mathrm{Fe}_{\mathrm{o}}\right.$ and $\mathrm{Al}_{\mathrm{o}}$ ) were obtained by extraction with $0.3 \mathrm{~mol} \mathrm{~L}^{-1}$ ammonium oxalate, at $\mathrm{pH} 3$ for 4 hours in a dark room (McKeague and Day, 1966). Extracted $\mathrm{Fe}$ and $\mathrm{Al}$ of $\mathrm{Al}_{0}$ and $\mathrm{Fe}_{\mathrm{o}}$ were filtered through a syringe filter with a $0.45 \mu \mathrm{m}$ pore size (Minisart RC 15, sartorius, Hannover, Germany). Contents of extracted $\mathrm{Fe}$ and $\mathrm{Al}$ were then determined by inductively coupled plasma-atomic emission spectroscopy (SPS1500, SEIKO).

Incubation experiment. $300 \mathrm{~g}$ (oven-dry weight) soil was weighed into a plastic pot and incubated with $\mathrm{CaSiO}_{3}$ (calcium silicate grade laboratory) for one month. A completely randomized design in double replication was set up. The experiment consisted of 3 levels of calcium silicate. Those were $0,2.5$ and $5 \%$ calcium silicate or $0,7.5$ and 15 g calcium silicate per pot. Deionized water was added to the pots to maintain the soil moisture around $85 \%$ of field capacity every second day gravimetrically. After the period of incubation, the soil samples were air-dried.

P sorption experiment. P sorption data were obtained using the procedure described by Fox and Kamprath (1970). Duplicate $3 \mathrm{~g}$ samples $(<2 \mathrm{~mm})$ were equilibrated in $30 \mathrm{~mL}$ of $0.01 \mathrm{~mol} \mathrm{~L}^{-1} \mathrm{CaCl}_{2}$ containing $\mathrm{P}$ at various concentrations $\left(0-100 \mathrm{mg} \mathrm{L}^{-1}\right)$ as $\mathrm{KH}_{2} \mathrm{PO}_{4}$ for 6 days at $25^{\circ} \mathrm{C}$. Two drops of toluene were added to suppress the microbial activity, and the suspension was shaken for 30 minutes twice daily. At the end of the equilibration period, the soil suspensions were centrifuged at $2500 \mathrm{rpm}$ for fifteen minutes and filtered (filter paper No. 6, Advantec Toyo, Tokyo, Japan). The amount of $P$ in the supernatant solution was determined by the procedure of Murphy and Riley (1962). The absorbance at $693 \mathrm{~nm}$ was determined using a UV-VIS spectrophotometer (UV-1200, Shimadzu Corporation, Japan). The amount of $\mathrm{P}$ sorbed by the soils was calculated as the difference between the amount of $\mathbf{P}$ added and the amount remaining in solution. The $P$ sorption data were fitted to the non linear of Langmuir equation, as described below:

\section{$q=K b c /(1+K c)$}

Where, $c=$ the equilibrium concentration of $P$ in the soil solution, $q=$ the quantity of $P$ sorbed per unit mass of sorbent, $b=P$ sorption maximum, $K=a$ constant related to the bonding energy of sorption. To determine the maximum sorption capacity (b) and bonding energy $(K)$, the equation was arranged in the linear form as below:

$$
\mathrm{c} / \mathrm{q}=\mathrm{c} / \mathrm{b}+1 / \mathrm{Kb}
$$

Standard $P$ requirement, which is expressed as the amount of $P$ sorbed when the equilibrium concentration was $0.2 \mathrm{mg} \mathrm{P} \mathrm{L}^{-1}$ was also determined.

P Sorption kinetic experiment. Duplicate $3 \mathrm{~g}$ samples $(<2 \mathrm{~mm})$ were equilibrated in $30 \mathrm{~mL}$ of $0.01 \mathrm{~mol}$ $\mathrm{L}^{-1} \mathrm{CaCl}_{2}$ containing $50 \mathrm{mg} \mathrm{P} \mathrm{L}{ }^{-1}$ as $\mathrm{KH}_{2} \mathrm{PO}_{4}$. Two drops of toluene were added to suppress the microbial activity.
The suspension was shaken for 1 minute (mint), 5 mint, 10 mint, 15 mint, 20 mint, 30 mint, 1 hour (h), $3 \mathrm{~h}, 6 \mathrm{~h}$ and $48 \mathrm{~h}$. As in P sorption experiment, in the end of the shaking period, the soil suspensions were centrifuged at $2500 \mathrm{rpm}$ fifteen minutes and filtered (filter paper No. 6, Advantec Toyo, Tokyo, Japan). $P$ content in the supernatant solution was determined by the procedure of Murphy and Riley (1962). The absorbance at $693 \mathrm{~nm}$ was determined using a UV-VIS spectrophotometer (UV-1200, Shimadzu Corporation, Japan). The amount of $\mathrm{P}$ sorbed by the soils was calculated as the difference between the amount of $P$ added and the amount remaining in solution. $P$ sorption kinetic experiments were conducted at $25^{\circ} \mathrm{C}$.

For describing the $P$ sorption kinetic, the data was fitted to first order kinetic equation as below.

$$
\text { P sorbed }=a\left(1-\mathrm{e}^{-k t}\right)
$$

where the constant $a$ is the $P$ sorbed maximum at given amount of $\mathrm{P}$ added in $\mathrm{mg} \mathrm{kg}^{-1}, k$ in $\mathrm{h}^{-1}$ is the rate constant of $P$ sorption and $t$ in $h$ is shaking period.

Statistical analyses. Analyses of variance followed by a Tukey's test were applied to evaluate the effect of calcium silicate to the parameters. SYSTAT 8.0 was used for the statistic analyses (SPSS Inc. 1998).

\section{RESULTS AND DISCUSSION}

\section{General physicochemical properties of the original soil}

As described in Hartono (2007), X-ray diffraction analysis showed that there was no peak observed in the diffractograms (Figure I). It suggested that all clay minerals in this soils was amorphous clay minerals. Allophane and amorphous $\mathrm{Al}$ and $\mathrm{Fe}$ oxides were probably dominant clay type in its amorphous clay minerals as reported by Tan (1965).

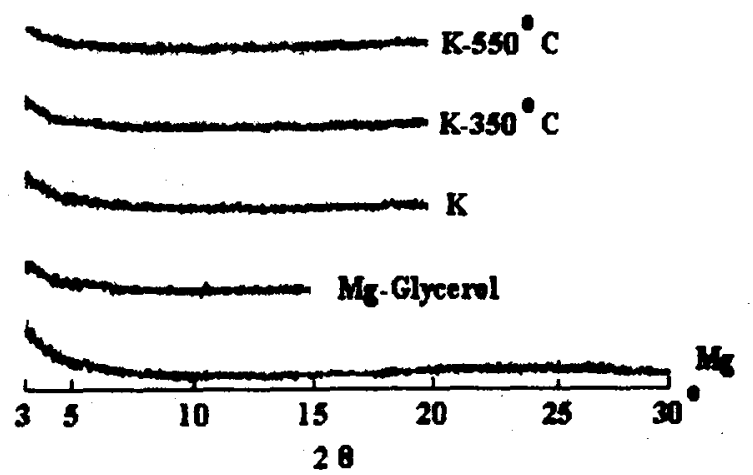

Figure 1. Diffractograms of X-ray Diffraction Analysis

Selected physicochemical properties of the soil is presented in Table 1. The criteria published by Soepratohardjo (1983) was used to judge some soil properties status. 
Table 1. Physicochemical Properties of Andisol Lembang and Their Status According to the Criteria of Center for Soil Research and Agroclimate (1983)

\begin{tabular}{|c|c|c|}
\hline Properties & Values & Status \\
\hline $\mathrm{pH} \mathrm{H}_{2} \mathrm{O}(1: 1.5)$ & 4.74 & Acid \\
\hline Organic C (\%) & 7.63 & Very high \\
\hline Clay (\%) & 24.3 & - \\
\hline $\operatorname{CEC}\left(\mathrm{cmol}_{\mathrm{c}} \mathrm{kg}^{-1}\right)$ & 30.1 & High \\
\hline $\mathrm{Ca}^{2+}\left(\mathrm{cmol}_{\mathrm{c}} \mathrm{kg}^{-1}\right)$ & 2.64 & Low \\
\hline $\mathrm{Mg}^{2+}\left(\mathrm{cmol}_{\mathrm{c}} \mathrm{kg}^{-1}\right)$ & 0.34 & Low \\
\hline $\mathrm{K}^{+}\left(\mathrm{cmol}_{\mathrm{c}} \mathrm{kg}^{-1}\right)$ & 0.10 & Low \\
\hline $\mathrm{Na}^{+}\left(\mathrm{cmol}_{\mathrm{c}} \mathrm{kg}^{-1}\right)$ & 0.21 & Low \\
\hline Base saturation (\%) & 10.9 & Very low \\
\hline Exchangeable $\mathrm{Al}\left(\mathrm{cmol} \mathrm{kg}^{-1}\right)$ & 0.93 & - \\
\hline Al saturation (\%) & & Medium \\
\hline Bray-1 P (mg kg ${ }^{-1}$ ) & 80.8 & Very high \\
\hline Total-P (mg kg-1) & 4783 & - \\
\hline $\begin{array}{l}\text { Oxalate: } \\
\operatorname{Al}\left(A I_{0}\right)(\%)\end{array}$ & 5.97 & - \\
\hline $\mathrm{Fe}\left(\mathrm{Fe}_{0}\right)(\%)$ & 2.11 & - \\
\hline $\mathrm{Al}_{0}+\mathrm{I} / 2 \mathrm{Fe}_{\mathrm{o}}(\%)$ & 7.03 & - \\
\hline
\end{tabular}

The soil reaction was acid while $\mathrm{Al}$ saturation of this soil was medium. The organic carbon was very high. CEC was high but $\mathrm{Ca}^{2+}, \mathrm{K}^{+}, \mathrm{Na}^{+}$status of this soil were low except $\mathrm{Mg}^{2+}$ was very low caused the base saturation low. Sum of percentage of $\mathrm{Al}$ plus half of $\mathrm{Fe}$ extracted by ammonium oxalate acid more than $2 \%$ typifies for Andisols. Bray I $\mathrm{P}$ was very high. Total-P which reached about $5000 \mathrm{mg} \mathrm{P} \mathrm{kg}^{-1}$ was concidered very high compared the other soils of upland soils (Hartono et al., 2006). It suggested that $P$ was really accumulated in this soil due to very intensive $P$ fertilization.

\section{P sorption parameters}

Langmuir $P$ sorption maxima, bonding energies and standard $P$ requirements ( $P$ sorbed at $0.2 \mathrm{mg} \mathrm{P} \mathrm{L}^{-1}$ ) as well as $R^{2}$ values for the Langmuir equation are presented in Table 2. The plot of $P$ in solution versus $P$ sorbed of original data and their Langmuir curves was presented in Figure 2. Table 2 showed that the $P$ sorption data were satisfactorily described by the Langmuir equation with regression coefficients ranging from 0.96 to 0.99 .

The results of $P$ sorption experiment showed that application of calcium silicate did not affect statistically $P$ sorption maximum although it tended to increase $\mathbf{P}$ sorption maxima (Table 2). The soil sample without addition of calcium silicate (control) had $\mathrm{P}$ sorption maximum 2500 $\mathrm{mg} \mathrm{kg}^{-1}$ while the soil sample with the application of $2.5 \%$ and $5.0 \%$ calcium silicate had $P$ sorption maximum 4167 and $3333 \mathrm{mg} \mathrm{P} \mathrm{kg}^{-1}$ respectively. On the other hand, the increasingly rates of calcium silicate was significantly to decrease $P$ bonding energy (Table 2). The control had $P$ bonding energy $9.00 \mathrm{~L} \mathrm{mg}^{-1}$ while the soil samples with the addition of $2.5 \%$ and $5.0 \%$ calcium silicate had $\mathrm{P}$ bonding energies 1.25 and $0.75 \mathrm{~L} \mathrm{mg}^{-1}$ respectively.
The results suggested that the addition of calcium silicate to the samples seemed to increase the $P$ sorption sites which resulted in higher $\mathbf{P}$ sorption maxima. But in fact the bonding was very weak as shown by their $P$ bonding energies which was about nine times weaker than the control. In the incubation period, sorption sites which were allophone and amorphous $\mathrm{Al}$ and $\mathrm{Fe}$ oxides were filled in by silicates through ligand exchange with hydroxyls in their molecule structure. Due to these occupation by silicates, therefore, added $P$ was adsorbed on the surface of minerals where the bonding type was van der Walls which the forces were very weak. It was shown in Hartono et al. (2006) that in the soils with low sorption sites the added $\mathrm{P}$ was in the labile $\mathrm{NaHCO}_{3} \mathrm{P}$ inorganic fraction which had low bonding energy. The other possibility was co-adsorption by calcium that was adsorbed by negative charges of soil colloids. The increasing rates of calcium silicate increased soil pH which enhanced the increase of cation exchange capacity or negative charges in this pH dependent charge soil (Hartono, 2007). Calcium acted as a bridge for $P$ sorption. It was possible that this electrostatic bonding was also very weak. Precipitation between calcium in the solution with $\mathrm{H}_{2} \mathrm{PO}_{4}$ did not occur according to the curve in Figure 2. The slope continued to flat suggested that the reaction was only adsorption by soil's particles.

The quantity of $P$ sorbed at the equilibrium $P$ concentration of $0.2 \mathrm{mg} \mathrm{P} \mathrm{L}^{-1}$ was reported to be the amount that will satisfy the $P$ requirement of many crops and is widely accepted as the standard $P$ requirement of soils (Fox and Kamprath, 1970; Juo and Fox, 1977). The amount of standard $P$ requirements or $P$ sorbed at $0.2 \mathrm{mg} \mathrm{P} \mathrm{L}^{-1}$ decreased with the increasing rates of calcium silicate. The addition of $5 \%$ calcium silicate decreased the standard $P$ requirements three times lower than control. In the range 
between 0 to $1.00 \mathrm{mg} \mathrm{P} \mathrm{L}^{-1}, \mathrm{P}$ sorbed in the samples treated by calcium silicate were much lower than that of control as shown in the Figure 2. It suggested that the higher $P$ sorption maximum was not a problem as long as the bonding energy was low.

Table 2. Equilibrium Langmuir Sorption Maxima (b), Bonding Energies (K), Standard $P$ Requirements of the Soils and $R^{2} V$ alue at $25^{\circ} \mathrm{C}$

\begin{tabular}{lcccc}
\hline Treatment & $\begin{array}{c}\text { Sorption maximum }(\mathrm{b}) \\
\left(\mathrm{mg} \mathrm{P} \mathrm{kg}^{-1}\right)\end{array}$ & $\begin{array}{c}\text { Bonding energy }(\mathrm{K}) \\
\left(\mathrm{L} \mathrm{mg}^{-1}\right)\end{array}$ & $\begin{array}{c}\text { P sorbed at } 0.2 \mathrm{mg} \mathrm{P} \mathrm{L}^{-1} \\
\left(\mathrm{mg} \mathrm{P} \mathrm{kg}^{-1}\right)\end{array}$ & $\begin{array}{c}\mathrm{R}^{2} \text { value of Langmuir } \\
\text { equation }\end{array}$ \\
\hline $\mathrm{Control}$ & $2500 \mathrm{a}$ & $9.00 \mathrm{a}$ & $1603 \mathrm{a}$ & 0.99 \\
$\mathrm{CaSiO}_{3} 2.5 \%$ & $4167 \mathrm{a}$ & $1.25 \mathrm{~b}$ & $80 \mathrm{~b}$ & 0.97 \\
$\mathrm{CaSiO}_{3} 5.0 \%$ & $3333 \mathrm{a}$ & $0.75 \mathrm{~b}$ & $435 \mathrm{c}$ & 0.96 \\
\hline
\end{tabular}

Means followed by the same letter within a column are not significantly different (Tukey`s test, $P<0.05$ )

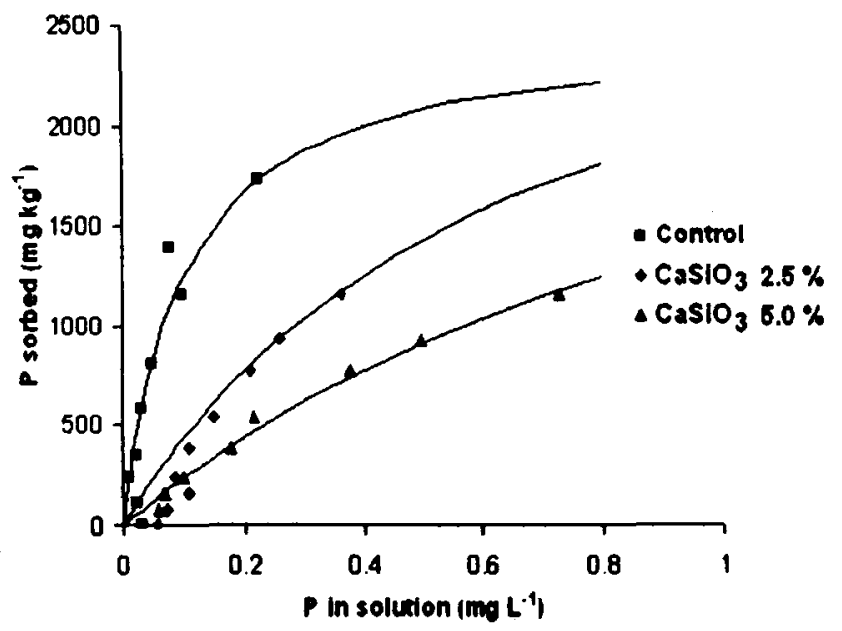

Figure 2. Langmuir Adsorption Isotherm for P Sorption by Soil Samples at $25^{\circ} \mathrm{C}$

\section{P sorption Kinetic}

The $P$ sorbed of samples in shaking period is presented in Table 3 and in Figure 3. To describe the $P$ sorption kinetic, the data was fitted to first order kinetic equation. The parameters of first order kinetic equation is presented in Table 4. The parameters $k$ and $a$ are the rate constant of $P$ sorption and $P$ sorbed maximum at given amount of added $P$ respectively.

Table 3. P-Sorbed at Different Shaking Time (minutes)

\begin{tabular}{lcccccccccc}
\hline & \multicolumn{10}{c}{ P sorbed (mg kg-1 } \\
\cline { 2 - 10 } \multicolumn{1}{c}{ Treatment } & 1 & 5 & 10 & 15 & 20 & 30 & 60 & 180 & 360 \\
\hline Control & 572 & 570 & 572 & 576 & 574 & 574 & 576 & 578 & 578 & 579 \\
$\mathrm{CaSiO}_{3} 2.5 \%$ & 556 & 560 & 558 & 575 & 564 & 568 & 571 & 575 & 576 & 579 \\
$\mathrm{CaSiO}_{3} 5.0 \%$ & 535 & 541 & 539 & 563 & 545 & 551 & 558 & 562 & 564 & 568 \\
\hline
\end{tabular}

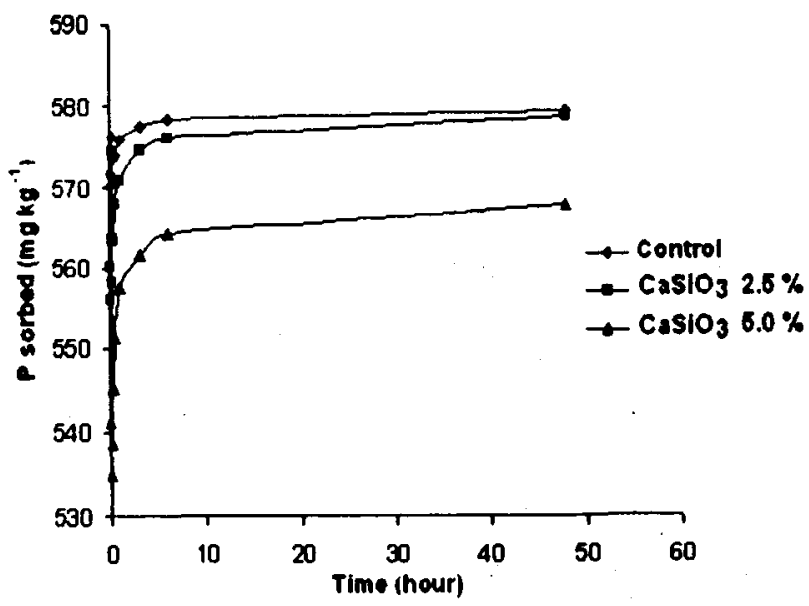

Figure 3. P sorption Kinetic by Soil Samples at $25^{\circ} \mathrm{C}$ 
Table 4. The Parameters of the Equation of the First Order Kinetic

\begin{tabular}{lccc}
\hline Treatment & $k$ & $\begin{array}{c}a \\
\left(\mathrm{mg} \mathrm{P} \mathrm{kg}^{-1}\right)\end{array}$ & $\mathrm{R}^{2}$ value of the equation \\
\hline Control & $\mathrm{h}^{-1}$ & $579 \mathrm{a}$ & 0.99 \\
$\mathrm{CaSiO}_{3} 2.5 \%$ & $5.47 \mathrm{a}$ & $576 \mathrm{a}$ & 0.99 \\
$\mathrm{CaSiO}_{3} 5 \%$ & $4.84 \mathrm{ab}$ & $564 \mathrm{~b}$ & 0.99 \\
\hline
\end{tabular}

Means followed by the same letter within a column are not significantly different (Tukey's test. $P<0.05$ )

Table 3 and Figure 3 showed that $P$ sorption was very fast. The added $P$ in this $P$ sorption kinetic experiment was $50 \mathrm{mg} \mathrm{P} \mathrm{L} \mathrm{L}^{-1}$ or equivalent with $579 \mathrm{mg} \mathrm{P} \mathrm{kg}^{-1}$. In one minute, almost $99 \%$ of added $P$ was sorbed by control soil. On soil samples treated with $2.5 \%$ and $5.0 \%$ calcium silicate, added $P$ were sorbed lower about $96 \%$ and $92 \%$ respectively. In the last shaking period $(48 \mathrm{~h})$ almost all added $\mathbf{P}$ was sorbed in control soil while soil samples treated with $2.5 \%$ and $5.0 \%$ of calcium silicate, added $P$ was sorbed about $99 \%$ and $98 \%$ respectively. The lower $P$ sorbed values on the samples treated by calcium silicate constantly showed in each shaking period. The sample treated by $5 \%$ of calcium silicate showed the lowest values of $P$ sorbed in each shaking period than those of the rest soil samples.

The $k$ value of soil sample treated by $5 \%$ of calcium silicate was statistically significantly lower than that of control (Table 4). Although the $k$ value of soil sample treated by $2.5 \%$ of calcium silicate was also lower than that of control but statistically was not different. As for $a$ value, soil sample treated by $5 \%$ of calcium silicate was statistically significantly lower than that of the rest soils (Table 4).

From the $\mathrm{P}$ sorption kinetic experiment, it is suggested that the occupation of sorption sites by silicate during incubation caused the added P sorbed slower than control. The lower $k$ values of soil samples treated by calcium silicate indicated that the added $\mathbf{P}$ would stay in the soil solution longer than control. The addition of calcium silicate to this soil not only lowered the bonding energy as shown in P sorption experiment but also delayed the added $P$ to be sorbed by soil particles.

\section{CONCLUSIONS}

Application of calcium silicate did not statistically affect $P$ sorption maxima of the soil samples but decreased significantly the $P$ bonding energies and standard $P$ requirement. It also lowered the rate constant of $P$ sorption and $P$ sorbed maximum at given amount of $P$ added in the $P$ sorption kinetic experiment.

The results suggested that the application of calcium silicate made the added $\mathrm{P}$ to this soil was more available for plant.

\section{ACKNOWLEDGMENTS}

I thank the farmers in Lembang for their assistance in the collection of the soil samples. I also thank Laboratory of Soil Science Graduate School of Agriculture, Kyoto University for providing materials and instruments for analyses.

\section{REFERENCES}

Beck, M. A., W. P. Robarge, and S.W. Buol. 1999. Phosphorus retention and release of anions and organic carbon by two Andisols. Eur. J. Soil Sci., 50: 157-164.

Birell, K. S. 1961. Ion fixation by allophane. New Zeal. J. Sci., 4:393-414.

Bray, R. H. and L. T. Kurtz. 1945. Determination of total, organic, and available forms of phosphorus in soils. Soil Sci., 59: 39-45.

Fassbender. H. W. 1968. Phosphate retention and its different chemical forms under laboratory conditions for 14 Costa Rica soils. Agrochimica, 6:512-521.

Fox, R. L. and E. J. Kamprath. 1970. Phosphate sorption isotherms for evaluating the phosphate requirements of soils. Soil Sci. Soc. Am. Proc., 34: 902-907.

Hartono, A. 2007. The effect of calcium silicate on selected chemical properties and transformation of inorganic and organic phosphorus in Andisol Lembang. Gakuryoku. XIII (3): 1-9.

Hartono, A., S. Funakawa, and T. Kosaki. 2006. Transformation of added phosphorus to acid upland soil with different soil properties in Indonesia. Soil Sci. Plant Nutr., 52:734-744.

Jeffries, C. D. 1947. A rapid method for the removal of free iron oxides in soils prior to petrographic analyses. Soil Sci. Soc. Am. Proc., 11:211-212.

Juo A. R. S. and R. L. Fox. 1977. Phosphate sorption characteristics of some benchmark soils of West Africa. Soil Sci., 124: 370-376.

Kingo, T. and P. F. Pratt. 1971. Nitrate adsorption. II. In competition with chloride, sulfate, and phosphate. Soil Sci. Soc. Amer. Proc., 35:725-728.

Kuo, S. 1996. Phosphorus. In: D. L. Spark, A. L. Page, P. A. Helmke, R. H. Loeppert, P. N. Soltanpour, M. A. Tabatai, C. T. Johnston, and M. E. Sumner, (eds.), Methods of Soil Analyses Part 3 Chemical Methods. ASA and SSSA, Madison, WI. 869-919.pp.

McKeague, J. A. and J. H. Day. 1966. Dithionite and oxalate extractable $\mathrm{Fe}$ and $\mathrm{Al}$ as aids in differentiating various classes of soils. Can. Soil Sci., 46:13-22.

Murphy, J. and J. P. Riley. 1962. A modified single solution method for determination of phosphate in natural waters. Anal. Chim. Acta., 27:31-36. 
Soepratohardjo M., Subagjo, H. Suhardjo, Ismangun, Marsoedi D. S, A. Hidayat, Y. Dai, A. Adi, M. Supartini, Mursidi, dan J. Sri Adiningsih S. 1983. Terms of Reference Survai Kapabilitas Tanah. Pusat Penelitian Tanah. Bogor.

SPSS Inc. 1998. SYSTAT 8.0 Statistics. 1086pp.

Tan, K. H. 1965. The Andosols in Indonesia. Soil Sci., 99:375-378.

Tan, K. H., and J. Van Schuylenborg. 1961. On the classification and genesis of soils developed over acid volcanic material under humid tropical conditions: II. Neth. J. Agr. Sci., 9: 41-54.

Van Ranst E., S. R. Utami, J. Vanderdeelen, J. Shamshuddin. 2004. Surface reactivity of Andisols on volcanic ash along the Sunda arc crossing Java Island, Indonesia. Geoderma, 123: 193-203.

Wada, K. 1959. Reactions of phosphate with allophane and halloysite. Soil Sci., 87:325-330. 